\title{
Perceived job insecurity as a risk factor for incident coronary heart disease: systematic review and meta-analysis
}

Marianna Virtanen professor ${ }^{1}$, Solja T Nyberg statistician ${ }^{1}$, G David Batty reader in epidemiology ${ }^{23}$, Markus Jokela senior research fellow ${ }^{4}$, Katriina Heikkilä specialist researcher ${ }^{1}$, Eleonor I Fransson senior lecturer ${ }^{567}$, Lars Alfredsson professor of epidemiology ${ }^{68}$, Jakob B Bjorner professor ${ }^{9}$, Marianne Borritz researcher $^{10}$, Hermann Burr scientist ${ }^{11}$, Annalisa Casini postdoctoral researcher ${ }^{12}$, Els Clays assistant professor ${ }^{13}$, Dirk De Bacquer professor ${ }^{13}$, Nico Dragano professor ${ }^{14}$, Marko Elovainio professor $^{15}$, Raimund Erbel professor of medicine ${ }^{16}$, Jane E Ferrie senior research fellow ${ }^{217}$, Mark Hamer principal research associate ${ }^{2}$, Karl-Heinz Jöckel professor ${ }^{18}$, France Kittel professor of health psychology and research methodology ${ }^{12}$, Anders Knutsson professor of public health ${ }^{19}$, Markku Koskenvuo professor of epidemiology ${ }^{20}$, Aki Koskinen statistician ${ }^{1}$, Thorsten Lunau researcher ${ }^{14}$, Ida E H Madsen researcher ${ }^{9}$, Martin L Nielsen senior registrar ${ }^{10}$, Maria Nordin lecturer in sociology ${ }^{21}$, Tuula Oksanen assistant chief medical officer ${ }^{1}$, Krista Pahkin team leader ${ }^{2}$, Jan H Pejtersen senior researcher $^{22}$, Jaana Pentti statistician ${ }^{1}$, Reiner Rugulies professor of psychosocial work environment research $^{923}$, Paula Salo professor ${ }^{124}$, Martin J Shipley statistician ${ }^{2}$, Johannes Siegrist professor ${ }^{14}$, Andrew Steptoe British Heart Foundation professor of psychology ${ }^{2}$, Sakari B Suominen professor $^{252627}$, Töres Theorell professor emeritus ${ }^{7}$, Salla Toppinen-Tanner team leader ${ }^{1}$, Ari Väänänen adjunct professor ${ }^{1}$, Jussi Vahtera professor of public health ${ }^{12628}$, Peter J M Westerholm professor emeritus ${ }^{29}$, Hugo Westerlund professor of epidemiology ${ }^{7}$, Natalie Slopen postdoctoral fellow $^{3031}$, Ichiro Kawachi professor of social epidemiology ${ }^{30}$, Archana Singh-Manoux research director $^{232}$, Mika Kivimäki professor of social epidemiology ${ }^{124}$, For the IPD-Work Consortium

${ }^{1}$ Finnish Institute of Occupational Health, FI-00250 Helsinki, Finland; ${ }^{2}$ Department of Epidemiology and Public Health, University College London, London, UK; ${ }^{3}$ Centre for Cognitive Ageing and Cognitive Epidemiology, University of Edinburgh, Edinburgh, UK; ${ }^{4}$ Institute of Behavioral Sciences, University of Helsinki, Helsinki, Finland; ${ }^{5}$ School of Health Sciences, Jönköping University, Jönköping, Sweden; ${ }^{6}$ Institute of Environmental Medicine, Karolinska Institutet, Stockholm, Sweden; ${ }^{7}$ Stress Research Institute, Stockholm University, Stockholm, Sweden; ${ }^{8}$ Centre for Occupational and Environmental Medicine, Stockholm County Council, Stockholm, Sweden; ${ }^{9}$ National Research Centre for the Working Environment, Copenhagen, Denmark; ${ }^{10}$ Department of Occupational and Environmental Medicine, Bispebjerg University Hospital, Copenhagen, Denmark; ${ }^{11}$ Federal Institute for Occupational Safety and Health (BAuA), Berlin, Germany; ${ }^{12}$ School of Public Health, Université Libre de Bruxelles, Brussels, Belgium; ${ }^{13}$ Department of Public Health, Ghent University, Ghent, Belgium; ${ }^{14}$ Institute for Medical Sociology, Medical Faculty, University of Düsseldorf, Düsseldorf, Germany; ${ }^{15} \mathrm{National}$ Institute for Health and Welfare, Helsinki, Finland; ${ }^{16}$ Department of Cardiology, West-German Heart Center Essen, University Duisburg-Essen, Essen, Germany; ${ }^{17}$ School of Community and Social Medicine, University of Bristol, Bristol, UK; ${ }^{18}$ Institute for Medical Informatics, Biometry, and Epidemiology, University Duisburg-Essen, Germany; ${ }^{19}$ Department of Health Sciences, Mid Sweden University, Sundsvall, Sweden; ${ }^{20}$ Department of Public Health, University of Helsinki, Finland; ${ }^{21}$ Department of Psychology, Umeå University, Umeå, Sweden; ${ }^{22}$ Danish National Centre for Social Research, Copenhagen, Denmark; ${ }^{23}$ Department of Public Health and Department of Psychology, University of Copenhagen, Copenhagen, Denmark; ${ }^{24}$ Department of Psychology, University of Turku, Turku, Finland; ${ }^{25}$ Folkhälsan Research Center, Helsinki, Finland; ${ }^{26}$ Department of Public Health, University of Turku, Finland; ${ }^{27}$ Nordic School of Public Health, Gothenburg, Sweden; ${ }^{28}$ Turku University Hospital, Turku, Finland; ${ }^{29}$ Occupational and Environmental Medicine, Uppsala University, Uppsala, Sweden; ${ }^{30}$ Department of Society, Human Development and Health, Harvard School of Public Health, Boston, MA, USA; ${ }^{31}$ Center for the Developing Child, Harvard University, Cambridge, MA, USA; ${ }^{32}$ Inserm U1018, Centre for Research in Epidemiology and Population Health, Villejuif, France 


\begin{abstract}
Objective To determine the association between self reported job insecurity and incident coronary heart disease.

Design A meta-analysis combining individual level data from a collaborative consortium and published studies identified by a systematic review.
\end{abstract}

Data sources We obtained individual level data from 13 cohort studies participating in the Individual-Participant-Data Meta-analysis in Working Populations Consortium. Four published prospective cohort studies were identified by searches of Medline (to August 2012) and Embase databases (to October 2012), supplemented by manual searches.

Review methods Prospective cohort studies that reported risk estimates for clinically verified incident coronary heart disease by the level of self reported job insecurity. Two independent reviewers extracted published data. Summary estimates of association were obtained using random effects models.

Results The literature search yielded four cohort studies. Together with 13 cohort studies with individual participant data, the meta-analysis comprised up to 174438 participants with a mean follow-up of 9.7 years and 1892 incident cases of coronary heart disease. Age adjusted relative risk of high versus low job insecurity was 1.32 (95\% confidence interval 1.09 to 1.59$)$. The relative risk of job insecurity adjusted for sociodemographic and risk factors was 1.19 (1.00 to 1.42). There was no evidence of significant differences in this association by sex, age ( $<50 v \geq 50$ years), national unemployment rate, welfare regime, or job insecurity measure.

Conclusions The modest association between perceived job insecurity and incident coronary heart disease is partly attributable to poorer socioeconomic circumstances and less favourable risk factor profiles among people with job insecurity.

\section{Introduction}

Intensified global economic competition is characterised by labour market deregulation, workplace downsizing, restructuring of companies in all sectors, and increased use of flexible forms of employment. These changes have modified patterns of employment such that jobs are becoming increasingly unstable and insecure. ${ }^{1-3}$ Recent global financial crises have resulted in job insecurity becoming commonplace ${ }^{45}$ and for many, a chronic stressor. ${ }^{6}$

Evidence for an association between job insecurity and health is accumulating, although much of the research is limited to cross sectional studies and self reported outcomes, such as psychological distress, physical symptoms, and poor self rated health. ${ }^{7-10}$ Coronary heart disease (CHD) remains a major public health issue. Psychosocial factors, such as work stress, have been implicated in its aetiology for decades, ${ }^{11-14}$ but surprisingly few published studies examined the relation between job insecurity and CHD. ${ }^{15-19}$ Of them, the two largest studies ${ }^{16} 18$ found job insecurity to be associated with higher, albeit statistically non-significant, risk of incident CHD. Other studies were small in scale and revealed discordant findings. ${ }^{15-19}$

Psychosocial factors typically have modest effects on CHD. ${ }^{20}$ Thus, it is possible that the existing studies have not been large enough to detect a potentially modest effect of job insecurity.
The relation is also suggested to vary by employee age, sex, or study context - that is, the national unemployment rate ${ }^{3}$ and type of welfare regime $e^{8}$-all of which are linked to factors that could increase the fear of adverse consequences, such as lack of re-employment opportunities and economic insecurity. ${ }^{721}$

To deal with these limitations, we conducted a systematic review and meta-analysis to summarise all available prospective evidence on perceived job insecurity and incident CHD. Our meta-analysis included individual participant data from 13 European cohort studies, ${ }^{20}$ and published studies retrieved by systematic review. This meta-analysis enabled us to quantify the association between job insecurity and incident, clinically verified $\mathrm{CHD}$ in a large variety of employee populations and more precisely than has previously been possible. In addition, the large sample size allowed us to carry out analyses stratified by sex, age group, national unemployment rate, type of welfare regime, and type of job insecurity assessed.

\section{Methods}

\section{Search strategy}

We conducted this meta-analysis according to the MOOSE (meta-analysis of observational studies in epidemiology) guidelines. ${ }^{22}$ We performed a systematic computerised search of the literature using "all fields" of Medline (PubMed; of articles indexed by August 2012) and Embase (by October 2012). We used the following search terms without restrictions: "job and insecurity" and "[coronary and heart and disease] or [cardiovascular and disease] or CVD or CHD or health." In addition, we scrutinised the reference list of all identified publications. We also searched cited references of these retrieved articles using the Institute of Scientific Information Web of Science (to October 2012) to identify all studies citing the included studies. Titles and abstracts were independently reviewed by two people (MV, MKi) to retrieve potentially relevant studies on the basis of a broad range of criteria for exposure (work exposure) and outcome (health) to further determine eligibility. Selected articles were reviewed (by MV, $\mathrm{MKi}$ ) to determine whether they met the inclusion criteria.

\section{Study selection criteria}

Studies meeting the following criteria were included in the meta-analysis: published in English; prospective design (cohort study) with individual level exposure and outcome data; examined the effect of self reported job insecurity (excluding indirect exposures such as organisational downsizing, anticipated factory closure, or contractual insecurity - that is, temporary employment) ${ }^{23}$; no prevalent $\mathrm{CHD}$ at baseline; and reported either estimates of relative risk, odds ratios, or hazard ratios with $95 \%$ confidence intervals, or data to calculate these.

\section{Data extraction from published studies}

We extracted the following information from each retrieved article: name of first author, start of follow-up for CHD (year), study location (country), population, number of participants, number of $\mathrm{CHD}$ events, mean follow-up time, mean age or age 
range, proportion of women, method of assessment of job insecurity, method of assessment of CHD, and covariates included in the adjusted models.

\section{Data from IPD-Work Consortium studies}

In a second approach, we included individual level data from the 13 European prospective cohort studies that represent the Individual-Participant-Data Meta-analysis in Working Populations (IPD-Work) Consortium. ${ }^{20}{ }^{24}$ Each constituent study in the consortium was approved by the relevant local or national ethics committee and all participants gave informed consent to participate. The IPD-Work data comprised 114033 employed men and women free of prevalent CHD with data for sex, age, job insecurity, and CHD outcome.

One of the published studies, the Whitehall II study, is also part of the IPD-Work Consortium. ${ }^{19}$ However, because the main outcome in the published study included incident angina cases, and the results were not reported by sex or age group, we pooled its data with the unpublished studies and re-analysed the data at the individual level.

\section{Assessment of contextual factors}

We used data on the national unemployment rate at the time of the baseline survey (mean rate if there were multiple years of data collection), from the International Labour Organization database (http://laborsta.ilo.org). The mean unemployment rate (7\%) across studies was chosen as the threshold to define high and low unemployment rate. The welfare typology was based on an earlier review that examined the association between flexible employment and health. ${ }^{8}$ The studies in our meta-analysis belonged to Scandinavian (Denmark, Finland, Sweden), Anglo-Saxon (United Kingdom, United States), and Bismarckian (Belgium, Germany) welfare regimes.

\section{Statistical analysis}

We used a two stage approach. In the first stage, we analysed the individual participant level data (IPD-Work) to generate hazard ratios and $95 \%$ confidence intervals at the study level within each of the 13 studies that used Cox proportional hazards models. We tested the proportional hazards assumption in the IPD-Work data and found no evidence for violation (all $\mathrm{P}>0.20$ ). In the second stage, conventional meta-analytical methods ${ }^{25}$ were used to combine the results from the IPD-Work analyses and the estimates of the four literature based publications in which the associations were reported as hazard ratios, ${ }^{18}$ relative risks, ${ }^{16}$ or odds ratios. ${ }^{15}{ }^{17}$ Because CHD incidence was low $(<10 \%)$ in the two cohorts reporting odds ratios, these estimates can be considered as close approximations of the relative risk. They were therefore combined with hazard ratio and relative risk estimates.

The minimally adjusted model was adjusted for age and stratified by sex. Multivariable adjusted models, combining men and women, were additionally adjusted for sex, socioeconomic status, smoking, alcohol consumption, body mass index, physical activity, total cholesterol, systolic blood pressure or hypertension, and diabetes (where data were available). We examined heterogeneity of the estimates using the $\mathrm{I}^{2}$ statistic and presented the summary estimates of the random effects analysis for the results.

To examine effect modification, we stratified the analysis of the association between job insecurity and CHD by sex, age group ( $<50$ years $v \geq 50$ years), ${ }^{20}$ and study level contextual factors - that is, national unemployment rate $(\leq 7 \% v>7 \%)$, type of welfare regime (Scandinavian, Anglo-Saxon,
Bismarckian), ${ }^{8}$ and type of exposure measure (perceived job insecurity in the present job $v$ perceived threat of lay-off or employment insecurity). Statistical significance of subgroup differences was determined on the basis of heterogeneity between subgroup estimates. We used SAS (version 9.2) to analyse study specific data, and the results of the meta-analyses were computed using Stata (MP version 11.1).

\section{Results}

\section{Literature search}

The search strategy identified 362 unique citations of which 29 were selected for further review (fig $1 \Downarrow$ ). Twenty five citations did not meet the inclusion criteria and were excluded. Of these, 17 were reviews ${ }^{2-39}$ and one was a meta-analysis of the health consequences of self reported job insecurity in which CHD was not separately analysed. ${ }^{9}$ The excluded papers also included two editorials, ${ }^{40}$ one glossary, ${ }^{41}$ one study based on ecological analysis, ${ }^{42}$ one study where the outcome was total mortality, ${ }^{43}$ and two cross sectional studies. ${ }^{44} 45$ Thus, four published studies met the inclusion criteria and were included in the present meta-analysis. ${ }^{15-18}$

From a manual search of the references of the retrieved relevant publications (including reviews) and the cited reference search of the articles that were selected for meta-analysis, we found 47 potentially relevant new articles and books. These new articles included 25 narrative or systematic reviews, ${ }^{11-66}$ two meta-analyses, ${ }^{367}$ seven editorials or commentaries, ${ }^{68-74}$ and five books and book chapters. ${ }^{21-78}$ Self reported job insecurity and health was the main topic of five narrative or systematic reviews, ${ }^{79-83}$ one meta-analysis, ${ }^{7}$ one editorial, ${ }^{84}$ and one study with a summary score of cardiovascular risk factors as an outcome instead of CHD. ${ }^{85}$ In this search procedure, we found no new individual studies meeting the inclusion criteria.

\section{Study characteristics}

The number of participants in the four published studies and 13 IPD-Work studies was up to 174438 (table $1 \Downarrow$ ), with 1892 events of incident CHD occurring during the mean follow-up period of 9.7 years (range 3.2-21.2). Although two studies were initiated in the 1980s, the baseline assessment for the remaining prospective studies was between 1992 and 2004. Six studies were from Denmark, ${ }^{17-90}$ three from Finland, ${ }^{91-93}$ two from the US, ${ }^{16}{ }^{18}$ two each from Sweden ${ }^{94} 95$ and Germany, ${ }^{15}{ }^{96}$ and one each from the $\mathrm{UK}^{97}$ and Belgium. ${ }^{98}$

\section{Assessment of job insecurity}

Table $2 \Downarrow$ presents the assessment of job insecurity across studies. Job insecurity was measured using a global single item question on the level of insecurity in the present job, ${ }^{15-97}$ or by questions on a fear of lay-off or unemployment, ${ }^{94-90}$ all dichotomised as high versus low job insecurity. In one published study, ${ }^{17}$ a four item multidimensional dichotomised scale was used with questions on fear of job loss, a transfer to another job, new technology, and re-employment prospects. Prevalence of job insecurity varied between $9.6 \%$ in the Blue Collar Study ${ }^{15}$ and $40.6 \%$ in the Whitehall II study. ${ }^{97}$

\section{Ascertainment of CHD}

CHD diagnosis was ascertained from hospital records or national death registers in all unpublished and published studies except in two IPD-Work studies (table 1). In the Belstress study, ${ }^{98}$ disease events were registered by the human resources department and occupational health service. In the 
Heinz-Nixdorf Recall study, ${ }^{96}$ possible cases were first identified by annual surveys and, in case of any suspicion of a cardiac event or in case of death, medical records were retrieved and the case validated by an expert panel at the local university hospital. In the remaining IPD-Work Consortium studies, date of diagnosis, hospital admission due to myocardial infarction, or date of death from CHD was used to define incident disease, as done previously. ${ }^{20}$

CHD cases were recorded according to criteria from the MONICA (Multinational monitoring of trends and determinants in cardiovascular disease) project, or codes from ICD-9 or ICD-10 (international classification of diseases, 9th or 10th revisions). We included all non-fatal myocardial infarctions that were recorded as I21-I22 (ICD-10) or 410 (ICD-9) and coronary deaths recorded as I20-I25 (ICD-10) or 410-414 (ICD-9) as the main diagnosis. Participants were followed from baseline to the earliest of the following dates: incident CHD event, death, or end of the registry follow-up. In two published studies (Nurses' Health Study, ${ }^{16}$ Women's Health Study ${ }^{18}$ ), self reported CHD events or those reported by next of kin were verified by medical records.

\section{Assessment of covariates}

All unpublished and published studies provided data on participants' age, sex, and socioeconomic status. Depending on the study, covariates for the adjusted models included these sociodemographic factors only ${ }^{18}$ or sociodemographic factors and health risk behaviours. ${ }^{86-91}$ Covariates in other studies included sociodemographic factors, health risk behaviours, and either self reported or biological CHD risk factors that were clinically verified (that is, blood pressure or hypertension, diabetes, or cholesterol level) and that also varied between studies (table 1). ${ }^{15-98}$ In the IPD-Work datasets, job insecurity and health risk behaviours (smoking [current, ex-smoker, or never smoker], physical activity [sedentary, active, or other], alcohol use [non-drinkers, moderate, intermediate, or heavy drinkers], and body mass index [underweight, normal, overweight, and obesity classes 1 to 3 ], were predefined and harmonised across the studies. ${ }^{20}{ }^{99}$ In the IPD-Work cohorts, socioeconomic status was based on the participant's highest occupational grade or educational qualification, and classified as low, intermediate, and high.

\section{Job insecurity and incident CHD}

Figure $2 \Downarrow$ shows the results from the random effects meta-analysis for the age adjusted association between job insecurity and incident CHD among men (15 studies) and women (13 studies) with 174438 participants and 1892 events of incident CHD. In the sex stratified analysis, women from two studies (the Heinz-Nixdorf Recall Study and Copenhagen Psychosocial Questionnaire version 2) were excluded owing to the low number of events $(\leq 2)$ during follow-up, leaving an analytical maximum sample of 171930 and 1890 events in this analysis. High job insecurity was associated with higher incidence of CHD among men (relative risk 1.24; $95 \%$ confidence interval 0.98 to 1.57 ), although the association was not significant. Among women, the relative risk of CHD for high job insecurity was 1.47 (1.07 to 2.02 ). The overall estimate suggested a relative risk of 1.32 (1.09 to 1.59) for high job insecurity among men and women. Some degree of heterogeneity was detected $\left(\mathrm{I}^{2}=40.7 \%\right.$ for the overall estimate $(\mathrm{P}=0.014), \mathrm{I}^{2}=43.7 \%$ among men $(\mathrm{P}=0.036)$, and $\mathrm{I}^{2}=37.3 \%$ among women $(\mathrm{P}=0.085))$.
Figure $3 \Downarrow$ shows the study specific results with multivariable adjustment. The Women's Health Study was excluded from this analysis, because neither health behaviour nor biological risk factor covariates were provided in the published article. This exclusion left a sample of 143572 with 1617 events. The overall estimate adjusted for age and sex was 1.32 (95\% confidence interval 1.08 to 1.62) without the Women's Health Study (data not shown in the figure). After adjustment for all covariates, the overall relative risk of job insecurity was 1.19 (1.00 to 1.42 , $\mathrm{P}=0.055$; with $\mathrm{I}^{2}=24.6 \%, \mathrm{P}=0.170$ ). The estimate was reduced by $41 \%$ compared with the minimally adjusted relative risk.

\section{Stratified analyses}

We examined whether the multivariable adjusted association between job insecurity and incident CHD was different between men and women, younger and older participants, across country specific contexts (based on the national unemployment rate and welfare regime), and whether the association varied according to the type of job insecurity assessed (web fig). In the age stratified analyses, the published Nurses' Health Study ${ }^{16}$ was included in the analyses of older employees, because only a small minority of participants were younger than 50 years. The Blue Collar Study ${ }^{15}$ was included in the analyses of younger employees whereas for the Copenhagen City Heart Study, ${ }^{17}$ age stratified results for men and women were provided. Among participants aged 50 or more, the adjusted relative risk was 1.26 (95\% confidence interval 1.02 to 1.57 ). As indicated by the overlapping point estimates and confidence intervals for the subgroups and the accompanying heterogeneity statistics, there was no clear evidence to suggest effect modification by age or other subgroup variables examined $(\mathrm{P}>0.10$ for all subgroup differences; web fig).

\section{Job insecurity and CHD risk factors}

The overall prevalence of job insecurity was $16.3 \%$ (table $3 \Downarrow$; table 2 shows the prevalence of each individual study). Participants with low socioeconomic status were more likely to report job insecurity. Regarding CHD risk factors, insecure participants were less likely to be physically active $(33.9 \% \mathrm{v}$ $37.3 \%)$ and had a higher prevalence of hypertension $(22.1 \% \mathrm{v}$ $20.1 \%)$ and hypercholesterolaemia $(51.1 \% v 46.6 \%)$ than secure participants. Differences in smoking, alcohol use, body mass index, and diabetes were relatively small.

\section{Discussion}

We aggregated results from published and unpublished studies within the context of a meta-analysis. The findings from 17 cohorts show that self reported job insecurity is associated with a small elevated risk of incident CHD, which was partly attributable to lower socioeconomic status and established risk factors for CHD. We found no statistical evidence to suggest effect modification of the association between job insecurity and CHD by sex, age, study context, or the type of job insecurity assessed.

\section{Strengths and limitations}

To our knowledge, with more than 170000 participants and 1800 incident cases of CHD, this is the largest study of job insecurity and incident CHD and provides the most comprehensive synthesis of evidence on this issue so far. Unlike meta-analyses of published studies, we were able to include unpublished studies in our meta-analysis, although the meta-analysis on unpublished data was restricted to studies participating in the IPD-Work Consortium. 
Because our data were based on US and European working populations, the generalisability of the findings to other contexts such as Asia or Africa is unclear. Our measurement of job insecurity was obtained at a single point in time and did not include assessment of the severity or the expected consequences of a potential job loss. In addition, chronic exposure to a stressor is usually more harmful than a one-off exposure, and previous studies have shown that chronic or repeated exposure to job insecurity or unstable labour market status might be more harmful to health than exposure to job insecurity at one time point only. ${ }^{6-101}$ Thus, our findings might underestimate the job insecurity-CHD association.

An important limitation, shared by all observational studies, is that we cannot make conclusions about causality. We are also unable to exclude residual confounding by imprecisely measured socioeconomic circumstances or CHD risk factors, or unmeasured confounding factors such as mental disorders-for example, depression - which might provide an alternative explanation for our findings. Depression could contribute to the job insecurity-CHD association in different ways. Depressed individuals may perceive their work environment, including their job security, more negatively; they may find it more difficult to obtain a secure job; job insecurity may also increase the risk of depression which, in turn, is a risk factor for developing CHD. Depression, negative mood, and perception of stress have been argued to represent the same underlying construct. ${ }^{102}$ However, it was not possible to investigate these processes in the present meta-analysis.

The number and content of the covariates in the fully adjusted models differed between studies, which could have caused some imprecision in the effect estimates. Finally, our systematic review was limited to English language publications, and we did not attempt to include all unpublished studies.

\section{Comparison with previous studies}

Earlier reviews and meta-analyses have found associations of self reported job insecurity with physical and psychological symptoms and self reported diseases, ${ }^{7-9}$ but our study is the first systematic review and meta-analysis of the prospective association between job insecurity and incident, clinically verified CHD. Four published studies-which are also included in our meta-analysis-suggest a higher risk of CHD among employees reporting high job insecurity, ${ }^{15-18}$ although three of them observed no statistically significant associations. ${ }^{15-18}$ In our meta-analysis, an association between job insecurity and CHD was found among employees aged 50 years or more, although the formal statistical test did not support the difference between the age groups.

Our meta-analysis, which includes both published and unpublished data, adds to the two existing large scale studies ${ }^{16} 18$ because it includes non-US employees in a wide range of occupations and is not limited to health professionals. In our meta-analysis, the association was also more precisely estimated because of larger numbers in the analysis.

Earlier evidence has suggested that long term job insecurity might be more devastating to health than a short term, transient exposure to job insecurity, ${ }^{6-101}$ although this effect was not possible to examine in the present study. However, not only the type of job contract but also other sources of insecurity—such as downsizing of personnel or a company closure-could have an adverse effect on employee health. ${ }^{28}$ Secondly, for an employee, the severity of a potential job loss may depend on the degree of dependence on the present job. ${ }^{71}$ If re-employment prospects are poor, job insecurity may be more stressful and more likely to actually lead to long term unemployment. These hypotheses should be examined in future studies.

\section{Interpretation of the findings}

The exact mechanisms underlying the job insecurity-CHD association are unknown, although the adjustment for socioeconomic status and CHD risk factors attenuated the relation between job insecurity and CHD. This attenuation indicated that these factors might either confound or mediate the association. One hypothesised mechanism is health risk behaviours, characterised by smoking, heavy alcohol use, physical inactivity, and overweight, ${ }^{14}$ which are also associated with low socioeconomic status. However, apart from lower physical activity, our analyses provided limited evidence to support health risk behaviours as the primary explanation for the job insecurity-CHD association. One further underlying mechanism could involve biological risk factors-such as hypertension, dyslipidaemia, and type 2 diabetes-we found a slightly higher prevalence of hypertension, type 2 diabetes, and hypercholesterolaemia among participants with job insecurity than among those who did not report job insecurity.

Our analyses were based on self reported job insecurity. There is debate as to whether job insecurity reflects the objective situation or an individual's subjective appraisal of that situation..$^{9-82}$ Concordance between subjective job insecurity and insecurity measured in an objective manner-for example, by personnel downsizing ${ }^{103}$ or a temporary job contract ${ }^{104}$ - has been reported, suggesting a degree of validity for self reported job insecurity.

\section{Conclusions and unanswered questions}

This meta-analysis provides evidence of a modest association between job insecurity and incident CHD. This association was found to be partly attributable to the poorer socioeconomic circumstances and less favourable profile of risk factors among people with job insecurity.

Several questions need further investigation. The extent to which other health conditions, such as mental disorders, contribute to the excess risk associated with job insecurity and CHD, remains unclear. In addition, job insecurity only represents part of the psychosocial work environment. Factors such as increased workload and decreased job control could partly mediate the effect of job insecurity on CHD, while other psychosocial factors (including support from supervisors, coworkers, and family members) could act as buffers. ${ }^{15-79}$ Another question is whether indirect, "objective" indicators of job insecurity (such as downsizing or temporary employment), financial insecurity, and a poor psychosocial work environment (such as high effort or demands, low control, and low social support at work) have additional health consequences. ${ }^{105}$

In summary, our findings suggest that perceived job insecurity seems to be, at best, a modest risk factor for CHD at the population level. However, we cannot rule out the possibility that it could still be harmful for coronary health in certain contexts, particularly for vulnerable individuals.

Contributors: MV was the principal investigator of this paper and along with MKi developed the hypothesis and study design and supervised this study. SN, MV, MJ, and IM performed statistical analysis. All authors contributed to study concept and design, analysis and interpretation of data, and drafting or critical revision of the manuscript for important intellectual content, or in addition, data acquisition. MKi, TT, RR, and ND obtained funding for the IPD-Work Consortium. SN and MKi had full access to all IPD-Work Consortium data in the study and take 


\section{What is already known on this topic}

Coronary heart disease remains a major public health problem; psychosocial factors, such as work stress, have been implicated in its cause

Although job insecurity has been linked to self reported symptoms of poor health, the relation between perceived job insecurity and incident coronary heart disease is unclear

\section{What this study adds}

This systematic review and meta-analysis summarised results from four published and 13 unpublished prospective studies on self reported job insecurity and coronary heart disease providing the most comprehensive synthesis of this issue so far

Summary estimates across these studies suggest a modest association between perceived job insecurity and incident coronary heart disease

This association was partly attributable to the worse socioeconomic circumstances and less favourable risk factor profiles among people reporting high job insecurity

responsibility for the integrity of the unpublished data and the accuracy of the data analysis. MV is guarantor.

Funding: The IPD-Work Consortium is supported by the EU New OSH ERA Research Program (funded by the Finnish Work Environment Fund, Finland; Swedish Research Council for Working Life and Social Research, Sweden; German Social Accident Insurance, Germany; and Danish Work Environment Research Fund), Academy of Finland (grants 132944 and 258598), and BUPA Foundation (grant 22094477). Funding bodies for each participating cohort study are listed on their websites. The sponsors had no role in the design and conduct of the study; collection, management, analysis, and interpretation of the data; and preparation, review, or approval of this manuscript.

Competing interests: All authors have completed the Unified Competing Interest form atwww.icmje.org/coi_disclosure.pdf (available on request from the corresponding author) and declare: support from the EU New OSH ERA Research Program, Academy of Finland, and BUPA Foundation for the submitted work; MKi is supported by the Medical Research Council (grant K013351) and the Economic and Social Research Council, UK, and the US National Institutes of Health (grants R01HL036310 and R01AG034454); AS is a British Heart Foundation professor; GDB is a Wellcome Trust Fellow; no other relationships or activities that could appear to have influenced the submitted work.

Ethical approval: Ethical approval was obtained for all studies providing individual participant data for the meta-analysis. All participants gave informed consent to participate.

Data sharing: No additional data available.

Organisation for Economic Co-operation and Development. OECD workers in the globa economy: increasingly vulnerable? In: OECD Employment Outlook. OECD, 2007:105-55. www.oecd.org/els/emp/40776761.pdf.

2 Ferrie J, Westerlund $\mathrm{H}$, Virtanen M, Vahtera J, Kivimäki M. Flexible labor markets and employee health. Scand J Work Environ Health Suppl 2008;6:98-110.

3 Virtanen M, Kivimaki M, Joensuu M, Virtanen P, Elovainio M, Vahtera J. Temporary employment and health: a review. Int J Epidemiol 2005:34:610-22.

4 Moynihan R. Job insecurity contributes to poor health. BMJ 2012;345:e5183.

5 Cornelissen T. Flexibility and security in the labour market. Labour market institutions and perceived job insecurity in Europe. International Labour Office: Subregional Office for Central and Eastern Europe, 2007. www.ilo.org/public/english/region/eurpro/geneva/ download/cornelissen report pd.

6 Ferrie JE, Shipley MJ, Stansfeld SA, Marmot MG. Effects of chronic job insecurity and change in job security on self reported health, minor psychiatric morbidity, physiological measures, and health related behaviours in British civil servants: the Whitehall II study. $J$ Epidemiol Community Health 2002;56:450-4.

7 Cheng GHL, Chan DKS. Who suffers more from job insecurity? A meta-analytic review. Appl Psychol Int Rev 2008;57:272-303.

8 Kim IH, Muntaner C, Vahid Shahidi F, Vives A, Vanroelen C, Benach J. Welfare states, flexible employment, and health: a critical review. Health Policy 2012;104:99-127.

9 Sverke M, Hellgren J, Naswall K. No security: a meta-analysis and review of job insecurity and its consequences. J Occup Health Psychol 2002;7:242-64.

10 Laszlo KD, Pikhart H, Kopp MS, Bobak M, Pajak A, Malyutina S, et al. Job insecurity and health: a study of 16 European countries. Soc Sci Med 2010;70:867-74.

11 Jenkins CD. Psychologic and social precursors of coronary disease (first of two parts). New Engl J Med 1971;284:244-55.

12 Jenkins CD. Medical progress. Recent evidence supporting psychologic and social risk factors for coronary disease (first of two parts). New Engl J Med 1976;294:987-94.

13 Cooper CL, Marshall J. Occupational sources of stress: a review of the literature relating to coronary heart disease and mental ill health. J Occup Psychol 1976;49:11-28.

14 Steptoe A, Kivimaki M. Stress and cardiovascular disease. Nat Rev Cardiol 2012;9:360-70.

15 Siegrist J, Peter R, Junge A, Cremer P, Seidel D. Low status control, high effort at work and ischemic heart disease: prospective evidence from blue-collar men. Soc Sci Med 1990;31:1127-34
16 Lee S, Colditz GA, Berkman LF, Kawachi I. Prospective study of job insecurity and coronary heart disease in US women. Ann Epidemiol 2004;14:24-30.

17 Netterstrom B, Kristensen TS, Jensen G, Schnor P. Is the demand-control model still a useful tool to assess work-related psychosocial risk for ischemic heart disease? Results from 14 year follow up in the Copenhagen City Heart study. Int J Occup Med Environ Health 2010;23:217-24

18 Slopen N, Glynn RJ, Buring JE, Lewis TT, Williams DR, Albert MA. Job strain, job insecurity, and incident cardiovascular disease in the Women's Health Study: results from a 10-year prospective study. PloS One 2012;7:e40512.

19 Ferrie JE, Kivimäki M, Shipley MJ, Davey Smith G, Virtanen M. Job insecurity and inciden coronary heart disease: the Whitehall II prospective cohort study. Atherosclerosis 2013, doi:10.1016/j.atherosclerosis.2012.12.027.

20 Kivimaki M, Nyberg ST, Batty GD, Fransson El, Heikkilä K, Alfredsson L, et al. Job strain as a risk factor for coronary heart disease: a collaborative meta-analysis of individual participant data. Lancet 2012;380:1491-7.

21 Hartley J, Jacobson D, Klandermans B, Van Vuuren T. Job insecurity: coping with jobs at risk. Sage, 1991

22 Stroup DF, Berlin JA, Morton SC, Olkin I, Williamson GD, Rennie D, et al. Meta-analysis of observational studies in epidemiology: a proposal for reporting. Meta-analysis Of Observational Studies in Epidemiology (MOOSE) group. JAMA 2000;283:2008-12.

23 Ferrie JE. Is job insecurity harmful to health? J R Soc Med 2001;94:71-6.

24 Heikkilä K, Nyberg ST, Theorell T, Fransson EI, Alfredsson L, Bjorner JB, et al. Work stress and cancer risk: a meta-analysis of 5700 incident cancer events in 116000 European men and women. BMJ 2013;346:f165.

25 Riley RD, Simmonds, MC, Look MP. Evidence synthesis combining individual patient data and aggregate data: a systematic review identified current practice and possible methods. J Clin Epidemiol 2007;60:431-9.

26 Benach J, Muntaner C, Solar O, Santana V, Quinlan M. Introduction to the WHO Commission on Social Determinants of Health Employment Conditions Network (EMCONET) study, with a glossary on employment relations. Int $J$ Health Serv 2010;40:195-207

27 Muntaner C, Solar O, Vanroelen C, Martínez JM, Vergara M, Santana V, et al. Unemployment, informal work, precarious employment, child labor, slavery, and health inequalities: pathways and mechanisms. Int J Health Serv 2010;40:281-95.

28 Quinlan M, Bohle P. Overstretched and unreciprocated commitment: reviewing research on the occupational health and safety effects of downsizing and job insecurity. Int $J$ Health Serv 2009;39:1-44

29 Menéndez M. Is precarious employment more damaging to women's health than men's? Soc Sci Med 2007;64:776-81.

30 Quinlan M. Organisational restructuring/downsizing, OHS regulation and worker health and wellbeing. Int J Law Psychiatry 2007;30:385-99.

31 Scott HK. Reconceptualizing the nature and health consequences of work-related insecurity for the new economy: the decline of workers' power in the flexibility regime. Int $J$ Health Serv 2004;34:143-53.

32 Ferrie JE. Health consequences of job insecurity. WHO Reg Publ Eur Ser 1999;81:59-99.

33 Marmot MG. Job insecurity in a broader social and health context. WHO Reg Publ Eur Ser 1999;81:1-9.

34 Ferrie JE. Labour market status, insecurity and health. J Health Psychol 1997:2:373-97.

35 Triolo PK. Occupational health hazards of hospital staff nurses. Part I: Overview and psychosocial stressors. AAOHN J 1989;37:232-7.

36 Siegrist J. Adverse health effects of high-effort/low-reward conditions. J Occup Health Psychol 1996;1:27-41

37 Lavis JN, Mustard CA, Payne JI, Farrant MS. Work-related population health indicators. Can J Public Health 2001;92:72-8.

38 Eller N, Netterström B, Gyntelberg F, Kristensen TS, Nielsen F, Steptoe A, et al. Work-related psychosocial factors and the development of ischemic heart disease. Cardio Rev 2009;17:83-97.

39 Nakao M. Work-related stress and psychosomatic medicine. Biopsychosoc Med 2010;4:4

40 Bartley M. Job insecurity and its effect on health. J Epidemiol Community Health 2005;59:718-9.

41 Bartley M, Ferrie J. Glossary: unemployment, job insecurity, and health. J Epidemiol Community Health 2001;55:776-81.

42 Kopp M, Skrabski A, Szanto Z, Siegrist J. Psychosocial determinants of premature cardiovascular mortality differences within Hungary. J Epidemiol Community Health 2006;60:782-8.

43 Perlman F, Bobak M. Assessing the contribution of unstable employment to mortality in posttransition Russia: prospective individual-level analyses from the Russian longitudinal monitoring survey. Am J Public Health 2009;99:1818-25.

$44 \mathrm{Xu} \mathrm{W}, \mathrm{Zhao} \mathrm{Y}, \mathrm{Guo} \mathrm{L}, \mathrm{Gao}$ W. The association between job insecurity and coronary hear disease in a Chinese population. World Congress of Cardiology vol 122, Beijing. China. Circulation 2010:e185.

45 Peltzer K, Shisana O, Zuma K, Van Wyk B, Zungu-Dirwayi N. Job stress, job satisfaction and stress-related illnesses among South African educators. Stress Health 2009;25:247-57. 
46 Siegrist J. Social reciprocity and health: new scientific evidence and policy implications. Psychoneuroendocrinology 2005;30:1033-8.

47 Kuper H. Systematic review of prospective cohort studies of psychosocial factors in the etiology and prognosis of coronary heart disease. Semin Vasc Med 2002;2:267-314.

48 Quinlan M, Mayhew C, Bohle P. The global expansion of precarious employment, work disorganization, and consequences for occupational health: a review of recent research. Int $J$ Health Serv 2001;31:335-414.

49 Sauter SL, Hurrel JJ Jr, Fox HR, Tetrick LE, Barling J. Occupational health psychology: an emerging discipline. Ind Health 1999;37:199-211.

50 Everson-Rose SA, Lewis TT. Psychosocial factors and cardiovascular diseases. Annu Rev Public Health 2005;26:469-500.

51 Kompier MA. New systems of work organization and workers' health. Scand J Work Environ Health 2006;32:421-30.

52 Kristensen TS. Cardiovascular diseases and the work environment. A critical review of the epidemiologic literature on nonchemical factors. Scand $J$ Work Environ Health 1989;15:165-79.

53 Kristensen TS. Challenges for research and prevention in relation to work and cardiovascular diseases. Scand J Work Environ Health 1999;25:550-7.

54 Landsbergis PA, Schnall PL, Belkic KL, Baker D, Schwartz J, Pickering TG. Work stressors and cardiovascular disease. Work 2001:17:191-208.

55 Low CA, Thurston RC, Matthews KA. Psychosocial factors in the development of heart disease in women: current research and future directions. Psychosom Med 2010;72:842-54

56 Matthews KA. Psychological perspectives on the development of coronary heart disease Am Psychol 2005;60:783-96.

57 Siegrist J. Effort-reward imbalance at work and cardiovascular diseases. Int J Occup Med Environ Health 2010;23:279-285.

58 Siegrist J, Siegrist K, Weber I. Sociological concepts in the etiology of chronic disease: the case of ischemic heart disease. Soc Sci Med 1986;22:247-53.

59 Peter R, Siegrist J. Psychosocial work environment and the risk of coronary heart disease. Int Arch Occup Environ Health 2000;73:S41-5.

60 Smith TW, Ruiz JM. Psychosocial influences on the development and course of coronary heart disease: current status and implications for research and practice. $J$ Cons Clin Psychol 2002;70:548-68.

61 Strike PC, Steptoe A. Psychosocial factors in the development of coronary artery disease. Prog Cardiovasc Dis 2004;46:337-47.

62 Tompa E, Scott-Marshall H, Dolinschi R, Trevithick S, Bhattacharyya S. Precarious employment experiences and their health consequences: towards a theoretical framework. Work 2007;28:209-24

63 Tsutsumi A, Kawakami N. A review of empirical studies on the model of effort-reward imbalance at work: reducing occupational stress by implementing a new theory. Soc Sci Med 2004;59:2335-59.

64 van Vegchel N, de Jonge J, Bosma H, Schaufeli W. Reviewing the effort-reward imbalance model: drawing up the balance of 45 empirical studies. Soc Sci Med 2005:60:1117-31.

65 Sparks K, Cooper CL. Well-being and occupational health in the 21st century workplace. J Occup Organ Psychol 2001;74:489-509.

66 Backe EM, Seidler A, Latza U, Rossnagel K, Schumann B. The role of psychosocial stress at work for the development of cardiovascular diseases: a systematic review. Int Arch Occup Environ Health 2012;85:67-79.

67 Kivimäki M, Virtanen M, Elovainio M, Kouvonen A, Väänänen A, Vahtera J. Work stress in the etiology of coronary heart disease: Systematic review and meta-analysis of prospective cohort studies. Scand J Work Environ Health 2006;32:431-42.

68 Benach J, Muntaner C. Precarious employment and health: developing a research agenda. $J$ Epidemiol Community Health 2007;61:276-7.

69 Benach J, Amable M, Muntaner C, Benavides FG. The consequences of flexible work for health: are we looking at the right place? J Epidemiol Community Health 2002;56:405-6.

70 Harma M, Kompier MA, Vahtera J. Work-related stress and health-risks, mechanisms and countermeasures. Scand J Work Environ Health 2006;32:413-9.

71 Landsbergis PA. The changing organization of work and the safety and health of working people: a commentary. J Occup Environ Med 2003;45:61-72.

72 Benach J, Muntaner C, Benavides FG, Amable M, Jodar P. A new occupational health agenda for a new work environment. Scand J Work Environ Health 2002;28:191-6.

73 Benach J, Benavides FG, Platt S, Diez-Roux A, Muntaner C. The health-damaging potentia of new types of flexible employment: a challenge for public health researchers. $A m \mathrm{~J}$ Public Health 2000;90:1316-7.

74 Hurrell JJ Jr. Are you certain? - uncertainty, health, and safety in contemporary work. Am $J$ Public Health 1998;88:1012-3.

75 Schnall PL, Belkic K, Landsbergis P, Baker D, eds. The workplace and cardiovascular disease. Hanley \& Belfus, 2000. Occupational Medicine State of the Art Reviews;15:1.

76 Hjemdahl P, Rosengren A, Steptoe A, eds. Stress and cardiovascular disease Springer-Verlag, 2012

77 Isaksson K, Hogstedt C, Eriksson C, Theorell T, eds. Health effects of the new labour market. Plenum, 2000

78 Stansfeld SA, Marmot MG, eds. Stress and the heart. BMJ Books, 2002.

79 De Witte H. Job insecurity: review of the international literature on definitions, prevalence, antecedents and consequences. SA J Ind Psychol 2005;31:1-6.

80 De Witte $\mathrm{H}$. Job insecurity and psychological well-being: review of the literature and exploration of some unresolved issues. Eur J Work Organ Psychol 1999;8:155-77.

81 Greenhalgh L, Rosenblatt Z. Job insecurity: toward conceptual clarity. Acad Manag Rev 1984;9:438-48.
82 Greenhalgh L, Rosenblatt Z. Evolution of research on job insecurity. Int Stud Manag Organ 2010;40:6-19.

83 Sverke M, Hellgren J. The nature of job insecurity: Understanding employment uncertainty on the brink of a new millennium. Appl Psychol Int Rev 2002;51:23-42.

84 Klandermans B, van Vuuren T. Job insecurity: introduction. Eur J Work Organ Psychol 1999;8:145-53.

85 Pelfrene E, Leynen F, Mak RP, De Bacquer D, Kornitzer M, De Backer G. Relationship of perceived job stress to total coronary risk in a cohort of working men and women in Belgium. Eur J Card Prev Reh 2003;10:345-54.

86 Nielsen M, Kristensen T, Smith-Hansen L. The intervention project on absence and well-being (IPAW): design and results from the baseline of a 5-year study. Work Stress 2002;16:191-206.

87 Kristensen TS, Hannerz H, Hogh A, Borg V. The Copenhagen Psychosocial Questionnaire- $\mathrm{a}$ tool for the assessment and improvement of the psychosocial work environment. Scand J Work Environ Health 2005;31:438-49.

88 Borritz M, Rugulies R, Bjorner JB, Villadsen E, Mikkelsen OA, Kristensen TS. Burnout among employees in human service work: design and baseline findings of the PUMA study. Scand J Public Health 2006;34:49-58.

89 Feveile H, Olsen O, Burr H, Bach E. Danish Work Environment Cohort Study 2005: from idea to sampling design. Stat Transit 2007;8:441-58.

90 Pejtersen JH, Kristensen TS, Borg V, Bjorner JB. The second version of the Copenhagen Psychosocial Questionnaire. Scand J Public Health 2010;38:8-24.

91 Vaananen A, Murray M, Koskinen A, Vahtera J, Kouvonen A, Kivimaki M. Engagement in cultural activities and cause-specific mortality: prospective cohort study. Prev Med 2009;49:142-7.

92 Korkeila K, Suominen S, Ahvenainen J, Ojanlatva A, Rautava P, Helenius H, et al. Non-response and related factors in a nation-wide health survey. Eur J Epidemiol 2001;17:991-9.

93 Kivimaki M, Lawlor DA, Davey Smith G, Kouvonen A, Virtanen M, Elovainio M, et al. Socioeconomic position, co-occurrence of behavior-related risk factors, and coronary heart disease: the Finnish Public Sector study. Am J Public Health 2007:97:874-9.

94 Peter R, Alfredsson L, Hammar N, Siegrist J, Theorell T, Westerholm P. High effort, low reward, and cardiovascular risk factors in employed Swedish men and women: baseline results from the WOLF Study. J Epidemiol Community Health 1998;52:540-7.

95 Alfredsson L, Hammar N, Fransson E, de Faire U, Hallqvist J, Knutsson A, et al. Job strain and major risk factors for coronary heart disease among employed males and females in a Swedish study on work, lipids and fibrinogen. Scand J Work Environ Health 2002;28:238-48.

96 Schmermund A, Mohlenkamp S, Stang A, Grönemeyer D, Seibel R, Hirche H, et al. Assessment of clinically silent atherosclerotic disease and established and novel risk factors for predicting myocardial infarction and cardiac death in healthy middle-aged subjects: rationale and design of the Heinz Nixdorf RECALL Study. Risk Factors, Evaluation of Coronary Calcium and Lifestyle. Am Heart J 2002;144:212-8.

97 Marmot MG, Davey Smith G, Stansfeld S, Patel C, North F, Head J, et al. Health inequalities among British civil servants: the Whitehall II study. Lancet 1991;337:1387-93.

98 De Bacquer D, Pelfrene E, Clays E, Mak R, Moreau M, de Smet P, et al. Perceived job stress and incidence of coronary events: 3-year follow-up of the Belgian Job Stress Project cohort. Am J Epidemiol 2005;161:434-41.

99 Nyberg ST, Heikkila K, Fransson El, Alfredsson L, De Bacquer D, Bjorner JB, et al. Job strain in relation to body mass index: pooled analysis of 160000 adults from 13 cohort studies. J Intern Med 2012;272:65-73.

100 Heaney CA, Israel BA, House JS. Chronic job insecurity among automobile workers: effects on job satisfaction and health. Soc Sci Med 1994;38:1431-7.

101 Rugulies R, Thielen K, Nygaard E, Diderichsen F. Job insecurity and the use of antidepressant medication among Danish employees with and without a history of prolonged unemployment: a 3.5-year follow-up study. J Epidemiol Community Health 2010;64:75-81.

102 Zapf D. Dormann C, Freze M. Longitudinal studies in organizational stress research: a review of the literature with reference to methodological issues. $J$ Occup Health Psychol 1996;1:145-69.

103 Kivimäki M, Vahtera J, Thomson L, Griffiths A, Cox T, Pentti J. Psychosocial factors predicting employee sickness absence during economic decline. J Appl Psychol 1997;82:858-72.

104 Virtanen M, Kivimäki M, Elovainio M, Vahtera J, Ferrie JE. From insecure to secure employment: changes in work, health, health-related behaviours, and sickness absence. Occup Environ Med 2003;60:948-53.

105 Ferrie JE, Shipley MJ, Newman K, Stansfeld SA, Marmot M. Self-reported job insecurity and health in the Whitehall II study: potential explanations of the relationship. Soc Sci Med 2005;60:1593-602.

Accepted: 23 July 2013

\section{Cite this as: BMJ 2013;347:f4746}

This is an Open Access article distributed in accordance with the Creative Commons Attribution Non Commercial (CC BY-NC 3.0) license, which permits others to distribute, remix, adapt, build upon this work non-commercially, and license their derivative works on different terms, provided the original work is properly cited and the use is non-commercial. See: http://creativecommons.org/licenses/by-nc/3.0/. 


\section{Tables}

\begin{tabular}{|c|c|c|c|c|c|c|c|c|c|c|}
\hline $\begin{array}{l}\text { Study, year } \\
\text { of entry }\end{array}$ & $\begin{array}{l}\text { Study } \\
\text { site }\end{array}$ & $\begin{array}{l}\text { Population } \\
\text { group, } \\
\text { participants } \\
\text { (No) }\end{array}$ & $\begin{array}{l}\text { CHD } \\
\text { events } \\
\text { (No) }\end{array}$ & $\begin{array}{c}\text { Incidence(per } \\
10000 \text { person } \\
\text { years) }\end{array}$ & $\begin{array}{l}\text { Follow-up } \\
(\text { years })^{*}\end{array}$ & $\begin{array}{c}\text { Age at } \\
\text { entry } \\
\text { (years) } \dagger\end{array}$ & $\begin{array}{l}\text { Proportion } \\
\text { (\%) of } \\
\text { women }\end{array}$ & CHD measure & $\begin{array}{c}\text { Covariates in } \\
\text { multivariable adjusted } \\
\text { model }\end{array}$ & $\begin{array}{l}\text { National } \\
\text { unemployment } \\
\text { rate }(\%)\end{array}$ \\
\hline \multicolumn{11}{|c|}{ Published studies } \\
\hline $\mathrm{BCS},{ }^{15} 1982$ & $\begin{array}{c}\text { West } \\
\text { Germany }\end{array}$ & $\begin{array}{l}\text { Blue collar } \\
\text { metal industry } \\
\text { employees } \\
(n=263)\end{array}$ & 21 & 122.8 & 6.5 & $40.8(9.7)$ & 0 & $\begin{array}{l}\text { MI or sudden } \\
\text { cardiac death; } \\
\text { clinical and } \\
\text { record } \\
\text { verification }\end{array}$ & $\begin{array}{c}\text { Age, BMI, systolic blood } \\
\text { pressure, } \\
\text { LDL-cholesterol, status } \\
\text { inconsistency, work } \\
\text { pressure, immersion }\end{array}$ & 3.8 (men) \\
\hline NHS, ${ }^{16} 1992$ & US & $\begin{array}{l}\text { Registered } \\
\text { nurses from } 11 \\
\text { largest US } \\
\text { states }(n=36 \\
910)\end{array}$ & 154 & 10.4 & 4 & $\begin{array}{c}55.2 \\
\text { (secure), } \\
54.8 \\
\text { (insecure) }\end{array}$ & 100 & $\begin{array}{l}\text { Non-fatal or } \\
\text { fatal CHD; self } \\
\text { reported or } \\
\text { reported by } \\
\text { next of kin, } \\
\text { record verified }\end{array}$ & $\begin{array}{l}\text { Age, smoking, alcohol } \\
\text { intake, BMI, } \\
\text { hypertension, diabetes, } \\
\text { hypercholesterolemia, } \\
\text { menopausal status, } \\
\text { current use of } \\
\text { post-menopausal } \\
\text { hormones, aspirin use, } \\
\text { past use of oral } \\
\text { contraceptives, } \\
\text { saturated fat intake, } \\
\text { vitamin E intake, } \\
\text { physical activity, } \\
\text { parental history of MI, } \\
\text { education, marital } \\
\text { status, husband's } \\
\text { education }\end{array}$ & 7.0 (women) \\
\hline $\mathrm{CCH},{ }^{17} 1993$ & Denmark & $\begin{array}{l}\text { Random } \\
\text { sample of } \\
\text { residents in } \\
\text { Copenhagen } \\
(n=1146)\end{array}$ & 104 & 64.8 & 14 & $30-67$ & 52 & $\begin{array}{c}\text { Hospital } \\
\text { admission or } \\
\text { death due to } \\
\text { CHD; register } \\
\text { based }\end{array}$ & $\begin{array}{l}\text { Age, SES, and coronary } \\
\text { risk factors (physical } \\
\text { activity, smoking, BMI, } \\
\text { systolic blood pressure) }\end{array}$ & 8.1 \\
\hline WHS, ${ }^{18} 1998$ & US & $\begin{array}{l}\text { Health } \\
\text { professionals } \\
\text { (90\% nurses; } \\
n=22 \text { 086) }\end{array}$ & 170 & 7.7 & 10 & $57.2(5.2)$ & 100 & $\begin{array}{l}\text { Non-fatal or } \\
\text { fatal MI; self } \\
\text { reported or } \\
\text { reported by } \\
\text { next of kin, } \\
\text { record verified }\end{array}$ & $\begin{array}{l}\text { Age, race, study drug } \\
\text { randomisation, } \\
\text { education, income }\end{array}$ & 4.6 (women) \\
\hline \multicolumn{11}{|c|}{ Unpublished studies } \\
\hline $\begin{array}{l}\text { Still Working, }{ }^{91} \\
1986\end{array}$ & Finland & $\begin{array}{l}\text { Employees in a } \\
\text { forestry } \\
\text { products } \\
\text { manufacturer } \\
(\mathrm{n}=6610)\end{array}$ & 538 & 38.4 & $21.2(4.3)$ & $40.9(9.2)$ & 21 & $\begin{array}{l}\text { Hospital } \\
\text { admission due } \\
\text { to non-fatal MI } \\
\text { or CHD death; } \\
\text { register based }\end{array}$ & $\begin{array}{c}\text { Age, sex, SES, } \\
\text { smoking, physical } \\
\text { activity, alcohol intake } \\
\end{array}$ & 5.4 \\
\hline Wolf-S,,$^{94} 1992$ & Sweden & $\begin{array}{l}\text { Employees } \\
\text { working in } \\
\text { private and } \\
\text { public } \\
\text { companies in } \\
\text { Stockholm } \\
\text { county } \\
(n=5640)\end{array}$ & 116 & 14.3 & $14.4(2.1)$ & $\begin{array}{c}41.5 \\
(11.0)\end{array}$ & 43 & $\begin{array}{l}\text { Hospital } \\
\text { admission due } \\
\text { to non-fatal MI } \\
\text { or CHD death; } \\
\text { register based }\end{array}$ & $\begin{array}{c}\text { Age, sex, SES, } \\
\text { smoking, physical } \\
\text { activity, BMI, alcohol } \\
\text { intake, diabetes, systolic } \\
\text { blood pressure, total } \\
\text { cholesterol }\end{array}$ & 7.3 \\
\hline $\begin{array}{l}\text { Belstress, }{ }^{98} \\
1994\end{array}$ & Belgium & $\begin{array}{l}\text { Employees in } \\
25 \text { large } \\
\text { companies in } \\
\text { public } \\
\text { administration } \\
(\mathrm{n}=14230)\end{array}$ & 85 & 18.7 & $3.2(1.0)$ & $45.6(6.0)$ & 0 & $\begin{array}{l}\text { Hospital } \\
\text { admission due } \\
\text { to non-fatal MI } \\
\text { or CHD death; } \\
\text { occupational } \\
\text { health service } \\
\text { records }\end{array}$ & $\begin{array}{c}\text { Age, sex, SES, } \\
\text { smoking, physical } \\
\text { activity, BMI, alcohol } \\
\text { intake, diabetes, systolic } \\
\text { blood pressure, total } \\
\text { cholesterol }\end{array}$ & 7.4 (men) \\
\hline
\end{tabular}


Table 1 (continued)

\begin{tabular}{|c|c|c|c|c|c|c|c|c|c|c|}
\hline $\begin{array}{l}\text { Study, year } \\
\text { of entry }\end{array}$ & $\begin{array}{l}\text { Study } \\
\text { site }\end{array}$ & $\begin{array}{l}\text { Population } \\
\text { group, } \\
\text { participants } \\
\text { (No) }\end{array}$ & $\begin{array}{l}\text { CHD } \\
\text { events } \\
\text { (No) }\end{array}$ & $\begin{array}{l}\text { Incidence(per } \\
10000 \text { person } \\
\text { years) }\end{array}$ & $\begin{array}{l}\text { Follow-up } \\
\text { (years) }^{*}\end{array}$ & $\begin{array}{c}\text { Age at } \\
\text { entry } \\
\text { (years) } \dagger\end{array}$ & $\begin{array}{l}\text { Proportion } \\
\text { (\%) of } \\
\text { women }\end{array}$ & CHD measure & $\begin{array}{c}\text { Covariates in } \\
\text { multivariable adjusted } \\
\text { model }\end{array}$ & $\begin{array}{l}\text { National } \\
\text { unemployment } \\
\text { rate }(\%)\end{array}$ \\
\hline $\begin{array}{l}\text { Whitehall II, }{ }^{97} \\
1995\end{array}$ & UK & $\begin{array}{l}\text { London based, } \\
\text { civil service } \\
\text { employees } \\
\quad(n=4866)\end{array}$ & 97 & 23.2 & $8.6(1.8)$ & $50.4(5.0)$ & 30 & $\begin{array}{l}\text { Hospital } \\
\text { admission due } \\
\text { to non-fatal MI } \\
\text { or CHD death; } \\
\text { register based }\end{array}$ & $\begin{array}{c}\text { Age, sex, SES, } \\
\text { smoking, physical } \\
\text { activity, BMI, alcohol } \\
\text { intake, diabetes, systolic } \\
\text { blood pressure, total } \\
\text { cholesterol }\end{array}$ & 8.4 \\
\hline Wolf-N,,$^{95} 1996$ & Sweden & $\begin{array}{l}\text { Employees of } \\
\text { private and } \\
\text { public } \\
\text { companies in } \\
\text { Jämtland and } \\
\text { Västernorrland } \\
\text { counties } \\
(n=4666)\end{array}$ & 132 & 24.6 & $11.5(1.3)$ & $\begin{array}{c}44.0 \\
(10.3)\end{array}$ & 17 & $\begin{array}{l}\text { Hospital } \\
\text { admission due } \\
\text { to non-fatal MI } \\
\text { or CHD death; } \\
\text { register based }\end{array}$ & $\begin{array}{c}\text { Age, sex, SES, } \\
\text { smoking, physical } \\
\text { activity, BMl, alcohol } \\
\text { intake, diabetes, systolic } \\
\text { blood pressure, total } \\
\text { cholesterol }\end{array}$ & 7.5 \\
\hline IPAW,$^{86} 1996$ & Denmark & $\begin{array}{l}\text { Employees of a } \\
\text { pharmaceutical } \\
\text { company, } \\
\text { municipal } \\
\text { technical } \\
\text { services, and } \\
\text { municipal } \\
\text { nursing homes } \\
\text { in Copenhagen } \\
(n=1685)\end{array}$ & 20 & 10.3 & $11.5(1.5)$ & $\begin{array}{c}41.9 \\
(10.6)\end{array}$ & 67 & $\begin{array}{l}\text { Hospital } \\
\text { admission due } \\
\text { to non-fatal MI } \\
\text { or CHD death; } \\
\text { register based }\end{array}$ & $\begin{array}{c}\text { Age, sex, SES, } \\
\text { smoking, alcohol intake }\end{array}$ & 6.2 \\
\hline $\begin{array}{l}\text { COPSOQ-I, }{ }^{87} \\
1997\end{array}$ & Denmark & $\begin{array}{l}\text { Population } \\
\text { based random } \\
\text { sample } \\
(n=1696)\end{array}$ & 33 & 16.6 & $11.7(1.7)$ & $\begin{array}{c}40.7 \\
(10.5)\end{array}$ & 48 & $\begin{array}{l}\text { Hospital } \\
\text { admission due } \\
\text { to non-fatal MI } \\
\text { or CHD death; } \\
\text { register based }\end{array}$ & Age, sex, SES, smoking & 6.1 \\
\hline $\begin{array}{l}\text { HeSSup, }{ }^{92} \\
1998\end{array}$ & Finland & $\begin{array}{l}\text { Age stratified, } \\
\text { population } \\
\text { based, random } \\
\text { sample }(n=15 \\
644)\end{array}$ & 62 & 5.7 & $7.0(0.4)$ & $\begin{array}{c}39.3 \\
(10.2)\end{array}$ & 56 & $\begin{array}{l}\text { Hospital } \\
\text { admission due } \\
\text { to non-fatal MI } \\
\text { or CHD death; } \\
\text { register based }\end{array}$ & $\begin{array}{c}\text { Age, sex, SES, } \\
\text { smoking, physical } \\
\text { activity, BMI, alcohol } \\
\text { intake, diabetes, } \\
\text { hypercholesterolaemia, } \\
\text { hypertension }\end{array}$ & 11.3 \\
\hline PUMA, ${ }^{88} 1999$ & Denmark & $\begin{array}{l}\text { Employees in } \\
\text { the human } \\
\text { service sector } \\
(n=1822)\end{array}$ & 17 & 9.3 & $10.0(1.1)$ & $\begin{array}{c}42.6 \\
(10.3)\end{array}$ & 83 & $\begin{array}{l}\text { Hospital } \\
\text { admission due } \\
\text { to non-fatal MI } \\
\text { or CHD death; } \\
\text { register based }\end{array}$ & $\begin{array}{c}\text { Age, sex, SES, } \\
\text { smoking, physical } \\
\text { activity, BMI, alcohol } \\
\text { intake }\end{array}$ & 5.1 \\
\hline FPS, ${ }^{93} 2000$ & Finland & $\begin{array}{l}\text { Public sector } \\
\text { employees ( } 10 \\
\text { towns, } 21 \\
\text { hospitals; } n=47 \\
064)\end{array}$ & 250 & 5.5 & $9.7(0.9)$ & $44.6(9.4)$ & 81 & $\begin{array}{l}\text { Hospital } \\
\text { admission due } \\
\text { to non-fatal MI } \\
\text { or CHD death; } \\
\text { register based }\end{array}$ & $\begin{array}{c}\text { Age, sex, SES, } \\
\text { smoking, physical } \\
\text { activity, BMI, alcohol } \\
\text { intake, diabetes, } \\
\text { hypertension }\end{array}$ & 9.3 \\
\hline $\mathrm{HNR},{ }^{96} 2000$ & Germany & $\begin{array}{l}\text { Random } \\
\text { sample of } \\
\text { residents in the } \\
\text { metropolitan } \\
\text { Ruhr area } \\
(n=1770)\end{array}$ & 38 & 26.5 & $8.1(1.3)$ & $53.3(4.8)$ & 41 & $\begin{array}{l}\text { Non-fatal MI or } \\
\text { sudden } \\
\text { cardiac death; } \\
\text { MI self } \\
\text { reported, ECG, } \\
\text { enzyme } \\
\text { based, record } \\
\text { verified }\end{array}$ & $\begin{array}{c}\text { Age, sex, SES, } \\
\text { smoking, physical } \\
\text { activity, BMI, alcohol } \\
\text { intake, diabetes, systolic } \\
\text { blood pressure, total } \\
\text { cholesterol }\end{array}$ & 8.6 \\
\hline $\begin{array}{l}\text { DWECS, }{ }^{89} \\
2000\end{array}$ & Denmark & $\begin{array}{l}\text { Population } \\
\text { based random } \\
\text { sample } \\
(\mathrm{n}=4967)\end{array}$ & 45 & 10.3 & $8.8(1.1)$ & $\begin{array}{c}41.4 \\
(10.8)\end{array}$ & 49 & $\begin{array}{l}\text { Hospital } \\
\text { admission due } \\
\text { to non-fatal MI } \\
\text { or CHD death; } \\
\text { register based }\end{array}$ & $\begin{array}{c}\text { Age, sex, SES, } \\
\text { smoking, physical } \\
\text { activity, BMI, alcohol } \\
\text { intake }\end{array}$ & 4.6 \\
\hline $\begin{array}{l}\text { COPSOQ-II, } \\
2004\end{array}$ & Denmark & $\begin{array}{l}\text { Population } \\
\text { based random } \\
\text { sample } \\
(n=3373)\end{array}$ & 10 & 5.9 & $5.0(0.4)$ & $\begin{array}{c}42.8 \\
(10.2)\end{array}$ & 53 & $\begin{array}{l}\text { Hospital } \\
\text { admission due } \\
\text { to non-fatal MI } \\
\text { or } \mathrm{CHD} \text { death; } \\
\text { register based }\end{array}$ & $\begin{array}{c}\text { Age, sex, SES, } \\
\text { smoking, physical } \\
\text { activity, BMI, alcohol } \\
\text { intake, diabetes, } \\
\text { hypertension }\end{array}$ & 5.3 \\
\hline
\end{tabular}


Table 1 (continued)

\begin{tabular}{|c|c|c|c|c|c|c|c|c|c|c|}
\hline $\begin{array}{l}\text { Study, year } \\
\text { of entry }\end{array}$ & $\begin{array}{l}\text { Study } \\
\text { site }\end{array}$ & $\begin{array}{l}\text { Population } \\
\text { group, } \\
\text { participants } \\
\text { (No) }\end{array}$ & $\begin{array}{l}\text { CHD } \\
\text { events } \\
\text { (No) }\end{array}$ & $\begin{array}{c}\text { Incidence(per } \\
10000 \text { person } \\
\text { years) }\end{array}$ & $\begin{array}{l}\text { Follow-up } \\
\text { (years) }^{*}\end{array}$ & $\begin{array}{l}\text { Age at } \\
\text { entry } \\
\text { (years)† }\end{array}$ & $\begin{array}{c}\text { Proportion } \\
\text { (\%) of } \\
\text { women }\end{array}$ & CHD measure & $\begin{array}{c}\text { Covariates in } \\
\text { multivariable adjusted } \\
\text { model }\end{array}$ & $\begin{array}{l}\text { National } \\
\text { unemployment } \\
\text { rate }(\%)\end{array}$ \\
\hline
\end{tabular}

BMI=body mass index; MI=myocardial infarction; LDL=low density lipoprotein; SES=socioeconomic status; BCS=Blue Collar Study; NHS=Nurses' Health Study; $\mathrm{CCH}=$ Copenhagen City Heart Study; WHS=Women's Health Study; WOLF-S=Work, Lipids, Fibrinogen-Stockholm; Belstress=Belgian Job Stress Project; WOLF-N=Work, Lipids, Fibrinogen-Norrland; IPAW=Intervention Project on Absence and Well-being; COPSOQ-I=Copenhagen Psychosocial Questionnaire Version 1; HeSSup=Health and Social Support Study; PUMA=Burnout, Motivation and Job Satisfaction Study; FPS=Finnish Public Sector Study; HNR=Heinz-Nixdorf Recall Study; DWECS=Danish Work Environment Cohort Study; COPSOQ-II=Copenhagen Psychosocial Questionnaire Version 2.

*Mean (standard deviation).

†Mean (standard deviation) or range. 


\begin{tabular}{|c|c|c|c|c|c|}
\hline Study & Measurement & No of items & Scale & Cut-point defining cases & Prevalence (\%) \\
\hline $\mathrm{BCS}^{15}$ & Job insecurity in one's own job & 1 & High to low & High & 9.6 \\
\hline $\mathrm{NHS}^{16}$ & My job security is good & 1 & $\begin{array}{c}\text { Strongly disagree, disagree, } \\
\text { agree, strongly agree }\end{array}$ & Strongly disagree, disagree & 17.6 \\
\hline $\mathrm{CCH}^{17}$ & $\begin{array}{l}\text { Are you worried that you 1) become } \\
\text { unemployed? 2) are transferred to other } \\
\text { job? 3) become superfluous due to new } \\
\text { technology? 4) have difficulties to find a } \\
\text { new job if unemployed with the } \\
\text { qualifications that you have? }\end{array}$ & 4 & Yes/no (to each item) & $\begin{array}{l}\text { High in the sum score (details } \\
\text { not available) }\end{array}$ & Not available \\
\hline $\mathrm{WHS}^{18}$ & My job security is good & 1 & $\begin{array}{l}\text { Strongly disagree, disagree, } \\
\text { agree, strongly agree }\end{array}$ & Strongly disagree, disagree & 19.4 \\
\hline Still Working ${ }^{91}$ & How secure is your present job? & 1 & $\begin{array}{l}\text { Very secure, rather secure, cannot } \\
\text { say, rather insecure, very insecure }\end{array}$ & $\begin{array}{c}\text { Very insecure, rather } \\
\text { insecure }\end{array}$ & 11.6 \\
\hline Wolf-S ${ }^{94}$ & Are you worried about becoming laid off? & 1 & Yes/no & Yes & 24.3 \\
\hline Belstress $^{98}$ & My employment security is good & 1 & $\begin{array}{c}\text { Strongly disagree, disagree, } \\
\text { agree, strongly agree }\end{array}$ & Strongly disagree, disagree & 11.6 \\
\hline Whitehall ${ }{ }^{97}$ & $\begin{array}{l}\text { How secure do you feel in your present } \\
\text { job? }\end{array}$ & 1 & $\begin{array}{c}\text { Very secure, secure, insecure, } \\
\text { very insecure }\end{array}$ & Very insecure, insecure & 40.6 \\
\hline Wolf-N ${ }^{95}$ & Are you worried about becoming laid off? & 1 & Yes/no & Yes & 28.5 \\
\hline IPAW $^{86}$ & $\begin{array}{l}\text { Are you worried about becoming } \\
\text { unemployed? }\end{array}$ & 1 & Yes/no & Yes & 27.7 \\
\hline COPSOQ-1 $-^{87}$ & $\begin{array}{l}\text { Are you worried about becoming } \\
\text { unemployed? }\end{array}$ & 1 & Yes/no & Yes & 18.9 \\
\hline HeSSup ${ }^{92}$ & $\begin{array}{c}\text { Does your job involve a threat of long } \\
\text { term unemployment? }\end{array}$ & 1 & $\begin{array}{l}\text { Very much, rather much, to some } \\
\text { degree, rather little, very little }\end{array}$ & $\begin{array}{l}\text { Very much, rather much, to } \\
\text { some degree }\end{array}$ & 13.0 \\
\hline $\mathrm{PUMA}^{88}$ & $\begin{array}{l}\text { Are you worried about becoming } \\
\text { unemployed? }\end{array}$ & 1 & Yes/no & Yes & 12.5 \\
\hline $\mathrm{FPS}^{93}$ & Does your job involve a threat of lay-off? & 1 & $\begin{array}{l}\text { Very much, rather much, to some } \\
\text { degree, rather little, very little }\end{array}$ & $\begin{array}{l}\text { Very much, rather much, to } \\
\text { some degree }\end{array}$ & 11.3 \\
\hline $\mathrm{HNR}^{96}$ & $\begin{array}{c}\text { Employment security is poor (yes/no). } \\
\text { How much does it distress you? }\end{array}$ & $1(2)$ & $\begin{array}{l}\text { Yes/no; very much, quite much, } \\
\text { to some extent, not at all }\end{array}$ & $\begin{array}{c}\text { Yes; very much, quite much, } \\
\text { to some extent }\end{array}$ & 11.8 \\
\hline DWECS $^{89}$ & $\begin{array}{c}\text { Are you worried about becoming } \\
\text { unemployed? }\end{array}$ & 1 & Yes/no & Yes & 17.3 \\
\hline COPSOQ- $-I^{90}$ & $\begin{array}{l}\text { Are you worried about becoming } \\
\text { unemployed? }\end{array}$ & 1 & $\begin{array}{l}\text { To a very high extent, to a high } \\
\text { extent, partially, to a low extent, } \\
\text { to a very low extent }\end{array}$ & $\begin{array}{l}\text { To a very high extent, to a } \\
\text { high extent, partially }\end{array}$ & 24.9 \\
\hline
\end{tabular}

BCS=Blue Collar Study; NHS=Nurses' Health Study; CCH=Copenhagen City Heart Study; WHS=Women's Health Study; WOLF-S=Work, Lipids, Fibrinogen-Stockholm; BELSTRESS=Belgian Job Stress Project; IPAW=Intervention Project on Absence and Well-being; WOLF-N=Work, Lipids, Fibrinogen-Norrland; COPSOQ-I=Copenhagen Psychosocial Questionnaire Version 1; HeSSup=Health and Social Support; PUMA=Burnout, Motivation and Job Satisfaction Study; DWECS=Danish Work Environment Cohort Study; FPS=Finnish Public Sector Study; HNR=Heinz-Nixdorf Recall Study; COPSOQ-II=Copenhagen Psychosocial Questionnaire Version 2. 


\begin{tabular}{|c|c|c|}
\hline \multirow[b]{2}{*}{ Characteristic (no of studies with data available for analysis) } & \multicolumn{2}{|c|}{ Self reported level of job insecurity } \\
\hline & $\begin{array}{c}\text { Secure } \\
\text { (overall prevalence 83.7\%) }\end{array}$ & $\begin{array}{c}\text { Insecure } \\
\text { (overall prevalence 16.3\%) }\end{array}$ \\
\hline Age $(n=15)^{*} \dagger$ & $47.9(9.0)$ & $47.7(9.1)$ \\
\hline \multicolumn{3}{|l|}{ Sex $(n=15)^{\star}$} \\
\hline Female & $100592(69.4)$ & $19615(69.6)$ \\
\hline Male & $44269(30.6)$ & $8553(30.4)$ \\
\hline \multicolumn{3}{|l|}{ Socioeconomic status $(\mathrm{n}=15)^{\star}$} \\
\hline High & $23608(16.5)$ & $2934(10.5)$ \\
\hline Intermediate & $91662(64.3)$ & $18658(66.9)$ \\
\hline Low & $27388(19.2)$ & $6310(22.6)$ \\
\hline \multicolumn{3}{|l|}{ Smoking $(n=15)$} \\
\hline Not smoking or ex-smoker & $108858(79.2)$ & 20660 (77.9) \\
\hline Current smoker & $28654(20.8)$ & $5847(22.1)$ \\
\hline \multicolumn{3}{|l|}{ Alcohol use $(n=13)$} \\
\hline None or average & $95432(88.6)$ & $17809(89.2)$ \\
\hline Heavy & $12270(11.4)$ & $2154(10.8)$ \\
\hline \multicolumn{3}{|l|}{ Physical activity $(n=13)$} \\
\hline High & $50902(37.3)$ & $8836(33.9)$ \\
\hline Low or moderate & $85659(62.7)$ & $17195(66.1)$ \\
\hline Body mass index $(n=12) \dagger$ & $25.6(4.1)$ & $25.9(4.4)$ \\
\hline \multicolumn{3}{|l|}{ Hypertension $(n=10)$} \\
\hline No & 99807 (79.9) & $18782(77.9)$ \\
\hline Yes & $25175(20.1)$ & $5330(22.1)$ \\
\hline \multicolumn{3}{|l|}{ Hypercholesterolaemia $(n=8)$} \\
\hline No & $44002(53.4)$ & 8921 (48.9) \\
\hline Yes & $38373(46.6)$ & $9308(51.1)$ \\
\hline \multicolumn{3}{|l|}{ Diabetes $(n=10)$} \\
\hline No & $121448(97.3)$ & $23213(96.7)$ \\
\hline Yes & $3320(2.7)$ & $796(3.3)$ \\
\hline
\end{tabular}

Data are number (\%) of participants unless otherwise stated.

*Data are available for all studies, but two published studies provided no information on the level of job insecurity.

†Mean (standard deviation). 


\section{Figures}

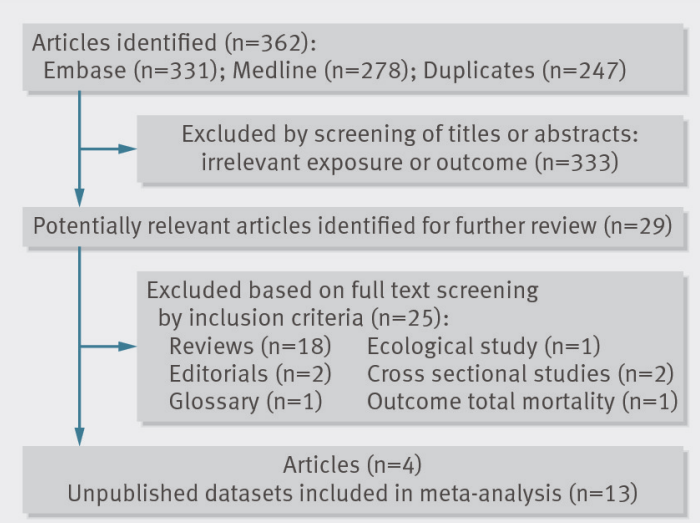

Fig 1 Flow diagram of studies included in the meta-analysis 


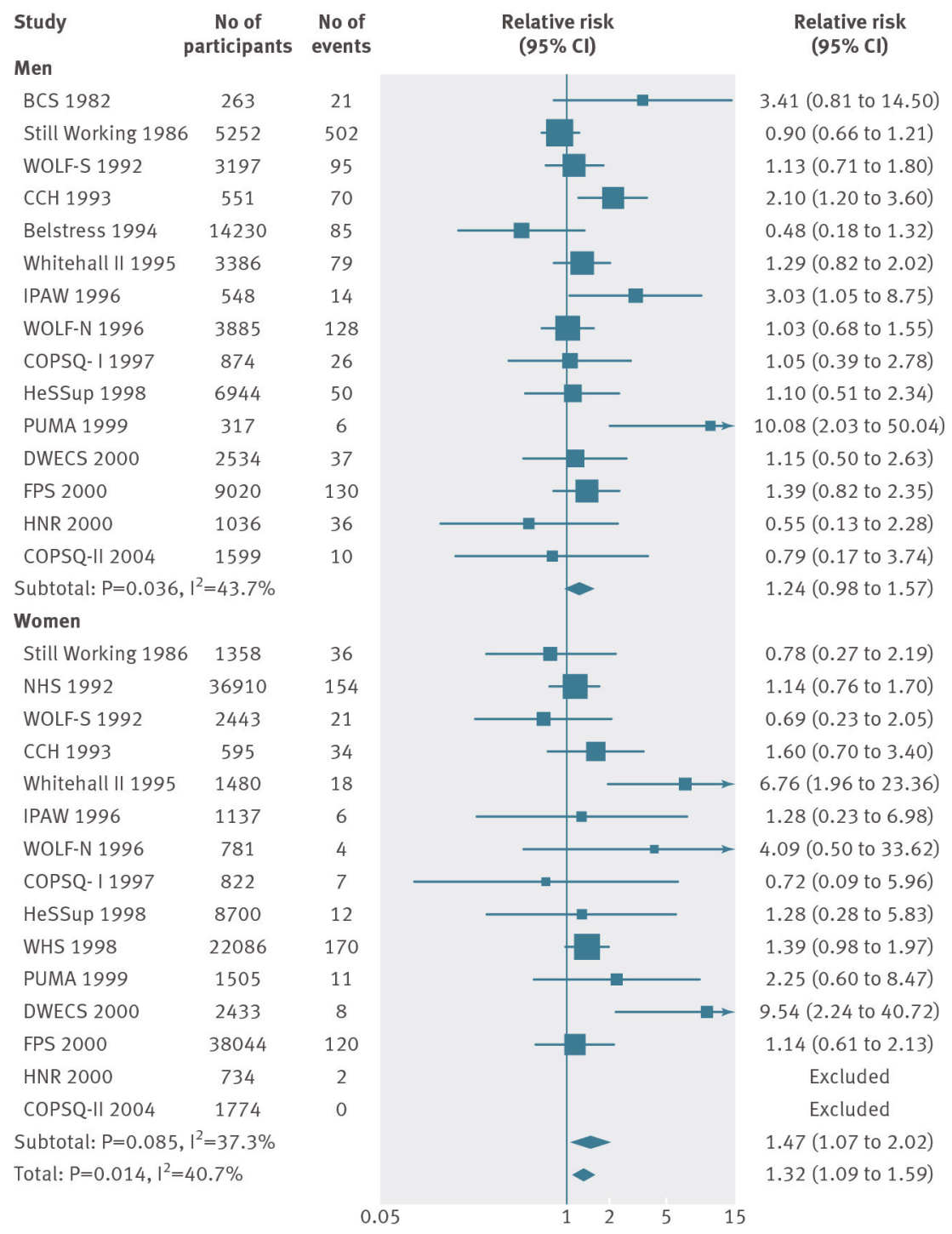

Fig 2 Forest plot of individual studies investigating the association between job insecurity and incident CHD events among men and women, adjusted for age. Models adjusted for age (apart from the Blue Collar Study, in which only the fully adjusted model was available; and the Women's Health Study, in which the model was adjusted for age, race, and drug randomisation). BCS=Blue Collar Study ${ }^{15}$; Still Working ${ }^{91}$; NHS=Nurses' Health Study ${ }^{16}$; $\mathrm{CCH}=$ Copenhagen City Heart Study ${ }^{17}$; Whitehall II Study ${ }^{97}$; WHS=Women's Health Study ${ }^{18}$; WOLF-S=Work, Lipids, Fibrinogen-Stockholm ${ }^{94}$; BELSTRESS=Belgian Job Stress Project ${ }^{98}$; IPAW=Intervention Project on Absence and Well-being ${ }^{86}$; WOLF-N=Work, Lipids, Fibrinogen-Norrland ${ }^{95}$; COPSOQ-I=Copenhagen Psychosocial Questionnaire version 1 ${ }^{87}$; HeSSup=Health and Social Support ${ }^{92}$; PUMA=Burnout, Motivation and Job Satisfaction Study ${ }^{88}$; DWECS=Danish Work Environment Cohort Study ${ }^{89}$; FPS=Finnish Public Sector Study93; HNR=Heinz-Nixdorf Recall Study96; COPSOQ-II=Copenhagen Psychosocial Questionnaire version $2^{90}$ 


\begin{tabular}{|c|c|c|c|c|}
\hline Study & $\begin{array}{l}\text { No of } \\
\text { articipants }\end{array}$ & $\begin{array}{l}\text { No of } \\
\text { events }\end{array}$ & $\begin{array}{l}\text { Relative risk } \\
\quad(95 \% \mathrm{Cl})\end{array}$ & $\begin{array}{l}\text { Relative risk } \\
(95 \% \mathrm{CI})\end{array}$ \\
\hline BCS 1982 & 263 & 21 & & $3.41(0.81$ to 14.50$)$ \\
\hline Still Working 1986 & 6400 & 508 & & $0.92(0.69$ to 1.23$)$ \\
\hline NHS 1992 & 36910 & 154 & & $1.04(0.69$ to 1.57$)$ \\
\hline WOLF-S 1992 & 5351 & 106 & & $1.04(0.66$ to 1.63$)$ \\
\hline CCH men 1993 & 551 & 70 & & $2.50(1.10$ to 5.60$)$ \\
\hline CCH women 1993 & 595 & 34 & & $1.40(0.50$ to 3.20$)$ \\
\hline Belstress 1994 & 13305 & 73 & & $0.42(0.13$ to 1.35$)$ \\
\hline Whitehall II 1995 & 4244 & 84 & & 1.63 (1.06 to 2.53$)$ \\
\hline IPAW 1996 & 1618 & 19 & & $2.47(0.99$ to 6.16$)$ \\
\hline WOLF-N 1996 & 4386 & 121 & & $0.98(0.63$ to 1.51$)$ \\
\hline COPSQ- I 1997 & 1690 & 33 & 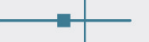 & $0.76(0.31$ to 1.84$)$ \\
\hline HeSSup 1998 & 14133 & 58 & & $1.19(0.60$ to 2.36$)$ \\
\hline PUMA 1999 & 1683 & 16 & & $2.22(0.73$ to 6.75$)$ \\
\hline DWECS 2000 & 4917 & 44 & & $1.72(0.88$ to 3.37$)$ \\
\hline FPS 2000 & 42563 & 231 & & $1.16(0.77$ to 1.75$)$ \\
\hline HNR 2000 & 1717 & 35 & & $0.66(0.16$ to 2.79$)$ \\
\hline COPSQ-II 2004 & 3246 & 10 & & $0.96(0.20$ to 4.64$)$ \\
\hline \multicolumn{3}{|c|}{ Total: $P=0.170, I^{2}=24.6 \%$} & 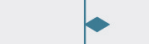 & 1.19 (1.00 to 1.42$)$ \\
\hline & & & 1 & \\
\hline
\end{tabular}

Fig 3 Forest plot of studies investigating the association between job insecurity and incident CHD, adjusted for multivariable analysis. Multivariable adjustment: age, sex, socioeconomic status, smoking, alcohol use, physical activity, body mass index, hypertension, hypercholesterolaemia, and diabetes (adjusted factors varied by study; table 1 shows a detailed list of adjusted covariates in different studies). BCS=Blue Collar Study ${ }^{15}$; Still Working ${ }^{91}$; NHS=Nurses' Health Study ${ }^{16}$; $\mathrm{CCH}=$ Copenhagen City Heart Study ${ }^{17}$; Whitehall II Study ${ }^{97}$; WOLF-S=Work, Lipids, Fibrinogen-Stockholm ${ }^{94}$;

BELSTRESS=Belgian Job Stress Project ${ }^{98}$; IPAW=Intervention Project on Absence and Well-being ${ }^{86}$; WOLF-N=Work, Lipids, Fibrinogen-Norrland ${ }^{95}$; COPSOQ-I=Copenhagen Psychosocial Questionnaire version 1 $^{87}$; HeSSup=Health and Social Support ${ }^{92}$; PUMA=Burnout, Motivation and Job Satisfaction Study ${ }^{88}$; DWECS=Danish Work Environment Cohort Study ${ }^{89}$; FPS=Finnish Public Sector Study ${ }^{93}$; HNR=Heinz-Nixdorf Recall Study ${ }^{96}$; COPSOQ-II=Copenhagen Psychosocial Questionnaire version $2 .{ }^{90}$ The Women's Health Study ${ }^{18}$ was excluded because no multivariable adjusted results were reported 